\title{
JUAL BELI ONLINE DI MASA PANDEMI COVID-19 DALAM PERSPEKTIF FIKIH MUAMALAH
}

\author{
Nasiri \\ STAI Taruna Surabaya \\ Email: nasiri.abadi20@gmail.com \\ Achmad \\ STAIS Bangkalan \\ Email : $\underline{\text { achmad.rosul@gmail.com }}$
}

\begin{abstract}
Abstrak : Jual beli online, di dalamnya, ada praktik wakalah, seller mewakilkan kepada reseller. Ada praktik ijarah, seller menyewa reseller untuk memasarkan barang dagangannya. Ada praktik ju'alah, seller mengumumkan (sayembara) kepada para reseller untuk berlomba-lomba memasarkan barangnya dengan bonus atau imbalan tertentu. Namun dalam kajian ini yang menjadikan penekanannya adalah akad jual belinya kepada para konsumen, bukan seller ke reseller, sehingga dengan demikian, jual beli online ini jika dilihat dalam perspektif fikih mu'amalah dapat dikategorikan sebagai akad jual beli yang sah, jika barang yang ditawarkan itu memang sudah ada. Akan tetapi jika barang belum ada, melainkan hanya gambar dan barangnya belum berwujud (belum dibuat), maka hal itu dikategorikan sebagai akad salam yang sah. Itupun jika ra'sul mal (uangnya) dibayar di awal, bukan sistem pembayaran di rumah (COD), namun jika dibayar di rumah, maka akad salam semacam ini, menurut para ulama fikih, tidak sah.
\end{abstract}

Kata Kunci : Jual Beli, Online.

\section{A. Pendahuluan}

Salah satu jenis jual beli yang menjadi buming dan digandrungi oleh banyak orang, khususnya di Indonesia, adalah jenis bisnis online atau lebih familier dengan sebutan jual beli online. Jual beli online semakin populer di saat pemerintah memberlakukan Pembatasan Sosial Beskala Besar (PSBB) atau sejenisnya ketika menghadapi Pademi Covid-19. Diberlakukannya PSBB atau PPKM di sebagian besar daerah seluruh Indonesia, maka roda perekonomian berubah menjadi digital. Semuanya memakai aplikasi. Mulai dari taksi onlie, ojek online, sekolah online, kuliah online, kerja online, ceramah agama online, sidang pengadilan online, jualan online, bahkan tahlil dan salawatan secara onlie.

Jual beli online, yang menjadi fokus pembahasan dalam tulisan, adalah satu terobosan bisnis yang sangat membantu banyak orang. Selain karena mudah dan dapat dioperasional dari rumahnya masing-masing, bisnis onlie ini tidak mebutuhkan dana besar, melainkan hanya butuh 
paket data yang harganya tidak terlalu besar, jika dibandingkan dengan harga barang-barang yang ditawarkan di publik.

Ada banyak barang yang bisa ditawarkan melalui online, bahkan bisa dikatakan semua barang bisa dijual belikan secara online. Mulain dari alat-alat sekolah, alat-alat dapur, alat-alat elektronik, kebutuhan SEMBAKO, semua jenis makanan, dan bahkan menawarkan jasa juga bisa dionlinekan. Salah satu contoh, penawaran jasa tukang bangunan, penawaran jasa kuli bangunan, penawaran jasa OB (office boy), penawaran asisten rumah tangga, dan lain sebagainya.

Dalam jual beli online ini, ada banyak media yang bisa dipake oleh para pebisnis online. Mulai dari media WA Gorup, Face Book, Instagram, Tweeter, dan sejenisnya. Semua bisa bisa dijadikan instrumen untuk menawarkan dagangan. Adapun praktiknya bermacam-macam, ada yang menawarkan barang dan saat ada konsumen tertarik bisa langsung chat pada pemilik barang, namun ada juga yang menawarkan barang melalui jasa aplikasi, sehingga saat konsumen tertarik pada barang itu, dia harus mengdownload aplikasi tersebut.

Sekilas jual beli online ini bisa dilakukan oleh semua orang dan konsumennya bisa terdiri dari semua kalangan masyarakat. Praktik jual beli online ini sepertinya mempermudah semua pihak dan menguntungkan banyak pihak. Namun sebenarnya ada masalah hukum yang harus dijelaskan atau dijawab dalam praktik jual beli online ini. Bagaimanakah jika salah satu pihak, khususnya konsumen, dirugikan? Misalnya, barang yang diterima tidak sesuai dengan barang yang ditawarkan atau barang yang dikirim tidak sesuai dengan kriteria pesanan konsumen. Lalu, bagaimanakah praktik jual beli online semacam ini jika dilihat dalam fikih muamalah? Di sinilah urgensinya kajiannya ini untuk tulis dan publis ke khalayak umum, agar bisa jelas dan terang benderang bagi seluruh masyarakat muslim, khususnya di Indonesia.

\section{B. Hukum Jual Beli dalam Islam}

Transaksi dengan orang lain itu kebutuhan pokok dalam kehidupan manusia. Artinya secara naluriyah manusia pasti ada kecenderungan untuk bertransaksi dengan sesama manusia. Transaksi itu banyak jenisnya. Mulai dari jual beli barang hingga jual beli jasa yang bermanfaat.

Terkait dengan hukum jual beli dalam Islam, sebelum adanya ijma' (konsesus ulama), dalam Al-Qur'an Surat al-Baqarah (275) Allah menegaskan bahwa jual beli hukum halal.

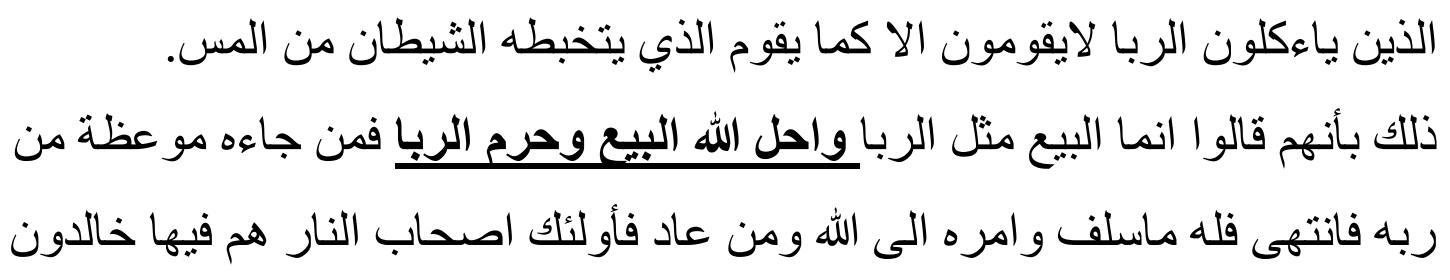

Orang-orang yang makan riba, tidak akan bisa berdiri kecuali seperti berdirinya orang yang kerasukan setan. Hal itu dikarenakan mereka berkata bahwasannya jual beli itu sama halnya dengan riba. Dan Allah menghalalkan praktik jual beli dan mengharamkan praktik riba. 
Barangsiapa yang mendapat wejangan dari Tuhannya, lalu kemudian berhenti dari praktik riba, maka yang diperoleh dahulu miliknya dan urusannya dikembalikan Allah swt. Namun jika orang itu mengulangi perbuatannya, maka mereka termasuk pemilik neraka dan akan kekal di dalamnya (QS. Al-Baqarah: 275) ${ }^{1}$

Selain itu, Rasulullah saw menegaskan dalam beberapa hadits yang populer, antara lain:

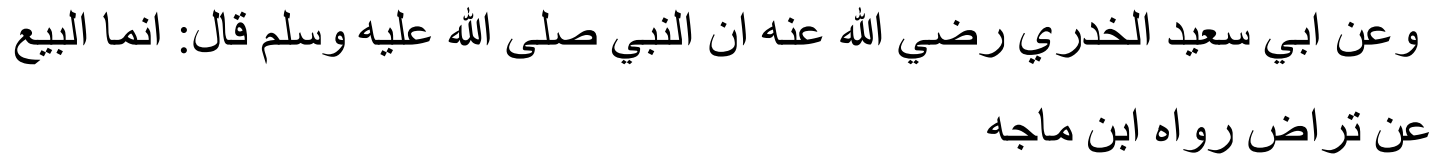

Dari Abi Said al-Khudri: Sesungguhnya jual beli itu harus didasari dengan kerelaan dari masing-masing pihak (penjual maupun pembeli) (HR. Ibnu Majah)

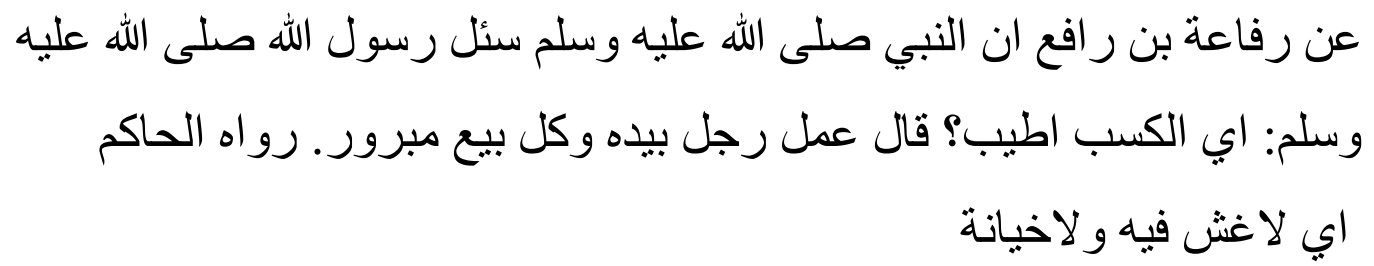

Dari Rifa'ah bin Rafi' bahwasannya Rasullah saw ditanya oleh Sahabatnya: pekerjaan apa yang paling bagus? Nabi menjawab: pekerjaan seseorang dengan tangannya sendiri (usaha sendiri) dan setiap jual beli yang baik (tidak penipuan dan tidak ada pengkhiatan di dalamnya) (HR. Al-Hakim). ${ }^{2}$

Dari keterangan ayat al-Qur'an dan hadits Nabi saw tersebut di atas, tentunya juga kesepakatan ulama, maka dapat ditegaskan kembali bahwa hukum jual beli dalam Islam itu halal, bahkan sangat dianjurkan agar bisa hidup mandiri tanpa merepotkan orang lain. Kebolehan jual beli ini, tentunya, tidak boleh ada unsur kebohongan atau penipuan. Dengan kata lain, baik pihak penjual maupun pihak pembeli, tidak boleh ada yang dirugikan sekecil apapun. Oleh karena itu, Nabi dalam hadits di atas menegaskan bahwa jual beli itu harus didasari saling rido, saling rela, dan saling ikhlas melepas barangnya atau menyerahkan uangnya.

\section{Ketentuan Jual Beli dalam Islam}

Dalam transaksi jual beli, banyak hal yang harus diperhatikan dalam Islam. Mulai syaratnya barang yang diperjualbelikan hingga rukun-rukun jual beli itu sendiri.

Dalam kesepatan mayoritas ulama fikih, ada tiga jenis barang yang diperjualbelikan dan ketiganya berbeda hukumnya. Ada yang boleh dan ada yang tidak diperbolehkan atau tidak sah jual belinya. ${ }^{3}$

\footnotetext{
${ }^{1}$ Kementerian Agama RI, Tafsir Kemenag RI, (Jakarta: Kemenag, 2010), hal. 275.

${ }^{2}$ Muhammad al-Hakim, Al-Mustadrak 'Ala Al-Sahihayn, (Beirut: Dar Al-Kutub Al-Ilmiah, t.t.), hal. 434.

${ }^{3}$ Muhammad Al-Syarqawi, Hasyiyah Al-Syarqari, (Libanon: Dar Al-Fikr, t.t.), hal. 147.
} 
Pertama, jual beli barang-barang yang bisa dilihat oleh mata (bay' 'ayn mushadah), atau bisa juga disebut dengan istilah jual beli barang yang ada di hadapan penjual dan pemberli. Jual beli barang seperti ini diperbolehkan dalam Islam, tentunya harus memenuhi unsur-unsur dalam jual beli. Misalnya, barang yang diperjualbelikan suci, bermanfaat, dan juga bisa diserahterimakan. Dengan kata lain, barang yang bisa dilihat atau ada di hadapan para pembeli atau penjual, namun jenis barang itu najis, maka tentu tidak boleh (haram) diperjualbelikan. ${ }^{4}$ Satu misal, menjual celetong atau kotoran hewan. Walaupun barangnya kelihatan, namun karena barangnya najis, maka jual beli celetong atau kotoran hewan itu tidak diperbolehkan dalam Islam. Menurut Syaikh Ibrahim al-Baijuri, barang yang diperjualbelikan, selain harus suci, juga diharuskan bermanfaat secara syari'at. ${ }^{5}$ Menurutnya, barang yang suci tidak semuanya boleh diperjual belikan, jika tidak bermanfaat. Menurut Syekh Muhammad Amin al-Kurdi, termasuk barang yang suci tapi tidak bermanfaat menurut syariat Islam adalah jual beli rokok. ${ }^{6}$ Walaupun, menurut hemat penulis, masalah rokok ini debatable atau masih diperselihkan oleh para ulama fikih. Paling tidak, dalam tulisan ini, penulis ingin menegaskan bahwa ada ulama yang tidak memperbolehkan jual beli rokok. Contoh lain, jual beli kalajengking, ular, kecoak, tikus, dan sejenisnya, semuanya tidak diperbolehkan sebab hewan-hewan tersebut secara syariat tidak ada manfaatnya. Selain harus suci dan bermanfaat. Barang yang akan diperjual belikan itu harus bisa diserahterimakan. Oleh karena itu, tidak diperbolehkan jual burung yang masih terbang di ruang angkasa atau masih ada di ruang bebas, sebab burung tersebut tidak bisa diserahkan kepada pembeli saat terjadi transaksi jual beli.

Kedua, jual beli barang yang ada dalam tanggungan penjual. Artinya calon pembeli menyebutkan kriterianya barang yang akan dibeli dan penjual menyiapkan atau mencarikan barang diinginkan oleh pembelinya. Jual beli semacam ini disebut dengan jual beli pesanan atau lebih dikenal dalam istilah fikih dengan akad salam. Jual beli semacam ini juga diperbolehkan asalkan barang yang diterima pembeli sesuai dengan pesanan. ${ }^{7}$ Misalnya, seorang pembeli memesan meja berukuran panjang 1 meter dan tinggi $50 \mathrm{~cm}$. Bahan terbuat dari kayu jati dan meja tidak perlu dicat melainkan hanya cukup dengan pletur. Penjual menyiapkan meja sesuai dengan kriteria tersebut, maka dalam contoh ini akad jual beli tersebut sah dan boleh dilakukan. Namun sebaliknya, jika pembeli menyiapkan barang (meja) tidak sesuai dengan kriteria yang disebutkan oleh pembeli, maka akad jual beli semacam ini tidak sah dan barang harus dikembalikan.

\footnotetext{
${ }^{4}$ Ibnu Qasim, Fathul Qarib, (Surabaya: Al-Hidayah, 19900), hal. 24.

${ }^{5}$ Ibrahim Al-Baijuri, Hasyiyah al-Baijuri 'ala Ibni Qasim al-Ghazi, Juz 1, (Jeddah: Al-Haramain, t.t.), hal. 341.

${ }^{6}$ Muhammad Amin Al-Kurdi, Tanwirul Qulub, (Bairut: Darul Kutub al-Ilmiah, t.t.), hal. 345.

${ }^{7}$ Ibrahim Al-Baijuri, Hasyiyah al-Baijuri, hal. 342.
} 
Ketiga, jual beli barang yang ghaib atau tidak kelihatan mata. Oleh karena jual beli barang ini harus kelihatan barangnya, maka menurut para ulama salaf, tidak diperbolehkan seorang yang tuna netra melakukan transaksi jual beli barang, terutama barang-barang yang berharga dan membutuhkan pengamatan yang jelas dari semua pihak. ${ }^{8}$

Selain memperhatikan barang yang diperjualbelikan, Islam juga mewajibkan adanya keterpenuhan unsur-unsur jual beli. Unsur-unsur jual beli dalam Islam ada enam (6) yang harus dipenuhi, yaitu: ${ }^{9}$

1. Adanya bai' (penjual). Tidak sah membeli barang dari toko atau warung yang tidak ada penjualnya, walaupun barangnya ada di tempat.

2. Adanya mushtari (pembeli). Tidak sah menjual barang kepada orang yang tidak nampak pembelinya.

3. Adanya muthman (barang yang diperjual belikan). Tidak sah membeli atau menjual barang yang belum ada barangnya, kecuali melalui akad salam atau akad pesanan sebagaimana penjelasan di atas.

4. Adanya thaman (harga/uang). Tidak mungkin terjadi jual beli barang kepada orang yang tidak punya uang atau tidak membawa uang.

5. Adanya ijab (akad dari penjual). Misalnya, penjual mengatakan "saya jual barang ini". Maka tidak sah jual beli yang tidak ada ijab dari penjual.

6. Adanya qabul (akad menerima dari pembeli). Misalnya, pembeli mengatakan "ya, saya beli barang ini”. Oleh karena itu, tidak sah jual beli barang yang tidak menggunakan akad semacam itu, kecuali jika barang-barang yang dijual itu barang kecil atau barang murahan, maka para ulama salaf memberikan rukhsah (toleransi) walaupun tidak memakai ijab qabul. ${ }^{10}$

\section{Jenis-Jenis Muamalah dalam Islam}

Dalam pembahasan muamalah, maka para ulama menguraikan varian jenis transaksi yang boleh dilakukan dan tentunya jenis transaksi yang tidak boleh dilakukan. Jenis-jenis transaksi itu sebagaimana berikut ini:

1. Akad Salam

Akad salam adalah akad jual beli barang yang belum ada namun pembeli menjelaskan secara detil barang yang diinginkannya. Menurut bahasa Syaikh AlBaijuri, bay' syayin mawsufin fi al-dzimmah (menjual sesuatu yang dijelaskan kriterianya dalam tanggungan penjual). ${ }^{11}$

\footnotetext{
${ }^{8}$ Abu Bakar Muhammad Syata, I'anat Al-Talibin, Juz III (Cairo: Dar al-Syuruq, t.t.), hal. 235.

${ }^{9}$ Abudrrahman Al-Jaziri, Al-Fiqh 'Ala Mazahib Al-Arba'ah, (Beirut: Dar Al-Kutub Al-Ilmiah, 2001), hal. 406.

${ }^{10}$ Ibid.

${ }^{11}$ Ibnu Hajar Al-Asqalani, Bulugh Al-Maram, (Cairo: Dar al-Syuruq, 2017), hal. 32
} 
Akad salam ini, sesuai kesepakatan ulama (ijma'), diperbolehkan untuk dilakukan oleh umat Islam, sebab akad ini sangat dibutuhkan dalam kelestarian ekonomi umat. ${ }^{12}$ Terkait dengan akad salam ini, al-Qur'an menjelaskan sebagai berikut:

\section{يايها الذين امنوا اذا تداينتم بلين اليى ا جل فاكتبوه. وليكتب بينكم}

كاتب بالعدل. و لا ياءب كاتب ان يكتب كما علمه الله. فليكتب وليملل الذي

$$
\text { عليه الحق وليتق الله ربه و لايبخس منه شيئا }
$$

Wahai orang-orang yang beriman, jika kalian berhutang suatu hutang hingga satu masa yang ditentukan, maka tulislah. Dan hendaknya seorang penulis menulisnya dengan adil. Dia tidak boleh menolak untuk menulisnya sebagaimana Allah telah mengajarkannya. Maka hendaknya dia menulis dan hendaknya orang yang memberi hutang itu mengimlaknya, dan hendaknya dia bertakwa kepada Allah, Tuhannya, dan janganlah mengurangi sedikitpun dari hutangnya (QS. Al-Baqarah: 282)

$$
\text { قال عبد الله ابن عباس رضي الله عنهما ان هذه الاية نزلت فى السلم }
$$

Menurut penuturan Abdullah bin Abbas, bahwa ayat ini diturunkan terkait masalah praktik akad salam.

Dalam riwayat Imam Al-Bukhari juga dijelaskan sebagai berikut:

$$
\begin{aligned}
& \text { عن ابن عباس رضي الله عنهما قال: قدم النبي صلى الله عليه وسلم } \\
& \text { المدينة وهم يسلفون فى الثمار السنة و السنتين فقال: من اسلف فى شيى } \\
& \text { فليسلف فى كيل معلوم ووزن معلوم الى اجل معلوم. رو اه البخاري }
\end{aligned}
$$

Dari Ibnu Abbas ra. Dia berkata: Nabi Muhammad saw tiba di Madinah dan penduduk Madinah biasa meminjamkan buahnya di masa setahun atau dua tahun. Maka Nabi saw bersabda: Barang siapa yang memesan sesuatu maka pesanlah dengan ukuran yang jelas, kriteria yang jelas, dan waktu yang jelas (HR. AlBukhari: 285).

$$
\begin{aligned}
& \text { وعن عبد الرحمن ابن ابزى و عبد الله بن ابي اوفى رضي الله عنهما } \\
& \text { قالا: كنا نصيب المغانم مع رسول الله صلى الله عليه وسلم وكان ياءتينا } \\
& \text { انباط من انباط الثام فنسلفهم فى الحنطة و الثعير و الزبيب وفى رواية } \\
& \text { والزيت الى اجل مسمى. قيل: اكان لهم زوع؟ قالا: ماكنا نسألهم عن ذلك }
\end{aligned}
$$

\footnotetext{
${ }^{12}$ Yusuf Al-Qrdawi, Norma dan Etika Ekonommi Syari'ah, terj. Zainal Arifin, (Jakarta: Gema Insani, 1997), hal. 67.
} 
Dari Abdurrahman bin Abza dan Abdullahbin Abi Awfa, mereka berdua berkata: kami menerima harta rampasan bersama Rasulillah saw dan datanglah beberapa petani dari Syam, lalu kami beri pinjaman kepada mereka berupa gandum, syair, dan anggur kering - dalam riwayat lain dan minyak - hingga masa tertentu. Ada yang bertanya: apakah mereka mempunyai tanaman? Mereka berdua menjawab: kami tidak menanyakan hal itu kepada mereka. (HR. AlBukhari: 876) ${ }^{13}$

Maksud dari hadits ini adalah tidak boleh memesan sesuatu yang tidak jelas krterianya. Misalnya, pesan meja namun tidak jelas ukurannya atau jelas ukurannya tapi tidak dijelaskan waktunya. Ini semua akan berpengaruh pada keabsahan dari akad tersebut. ${ }^{14}$

Adapun unsur-unsur yang harus dipenuhi dalam akad salam ini ada lima (5), yaitu: $:^{15}$

a. Muslim atau orang yang pesan (pembeli).

b. Muslam ilaih atau orang yang menerima pesan (penjual)

c. Muslam fih atau barang yang dipesan (barang)

d. Ra'su mal atau uang seharga barang pesanan dan harus diserahkan di awal, tidak boleh dihutang.

e. Shighat atau biasa disebut dengan istilah ijab qabul.

Ketia kelima hal ini terpenuhi, maka akad salam tersebut hukum sah dan halal. Namun sebaliknya, jika salah satu unsur ini tidak terpenuhi maka akad salamnya tidak dan tidak halal.

\section{Akad Wakalah}

Akad wakalah - ada yang baca wikalah namun tidak populer-adalah mewakilkan tugas atau pekerjaan kepada orang yang cakap hukum. Artinya, tidak boleh mewakilkan tugas atau pekerjaan kepada orang yang tidak cakap hukum. ${ }^{16}$

Akad wakalah ini akad yang boleh dan sah dalam Islam. Kedua belah pihak, muwakkil (yang mewakilkan) dan wakil (yang menerima wakalah) boleh membatalkan akadnya kapan saja, tentunya seusai dengan kesepakatan dari awal. Akad wakalah ini bisa batal jika salah satu di antara muwakkil dan wakil meninggalkan dunia. Begitu juga, saat salah satunya mengalami gangguan kejiwaan seperti gila, ayan-ayanan, atau setres. ${ }^{17}$

\footnotetext{
${ }^{13}$ Ibid. Hal. 876. Lihat juga Ibnu Hajjaj Muslim, Shohih Muslim, (Cairo: Dar Ihya' Al-Kutub Al-'Arabiyah, t.t.), hal. 675 .

${ }^{14}$ Ibnu Hajar Al-Asqalani, Fath Al-Bari, (Cairo: Dar Al-Ilm, 2000), hal. 1257

${ }^{15}$ Yusuf Al-Qardawi, Al-Fiqh al-Mu'asir, (Qatar: Al-Asyraq, 2003), hal. 89.

${ }^{16}$ Wahbah Al-Zuhayli, Al-Fiqh al-Islami wa Adillatuh, (Beirut: Dar Al-Kutuh Al-Ilmiah, 2004), hal. 387.

${ }^{17}$ Zainuddin Al-Malibari, Fathul Mu'in, (Surabaya: Al-Hidayah, 2018), hal. 45.
} 
Dalam akad wakalah ini, pihak wakil (orang yang menerima wakalah) bisa dipercaya dalam setiap tindakannya, baik menerima maupun mengeluarkan barang atau harta. Oleh karena itu, jika suatu hari ada kerugian atau ada masalah maka pihak wakil tidak bisa dimintai ganti rugi tentunya tidak bisa dituntut sebab akad wakalah ini kepercayaan dari seorang muwakkil kepada wakil. Beda halnya, jika kerugian atau kesalahan itu diakibatkan dari sikap teledor atau kesembronoan dari pihak wakil, maka dalam kasus seperti ini, pihak wakil boleh dituntu dan dimintai tanggung jawab. ${ }^{18}$

Akad wakalah dalam bidang ekonomi, seorang wakil boleh melakukan transaksi jual beli jika memenuhi tiga syarat berikut ini:

a. Menjual barang atau membeli barang itu dengan harga umum. Artinya harga barang itu sesuai dengan harga barang pada umumnya. Tidak boleh lebih tinggi dan tidak boleh lebih rendah.

b. Melakukan transaksi itu harus kontan, tidak boleh hutang.

c. Transaksi itu tentunya harus memakai mata uang yang berlaku di negara tempat tinggal dia. Artinya, jika di Indonesia, maka transaksi itu boleh dilakukan mata uang rupiah atau mata uang dunia, seperti Dollar, Uero, dan sejenisnya.

Dalam akad wakalah, kewenangan wakil, tidak boleh melebihi atau kurang dari apa yang diinginkan muwakkil. Artinya, di saat muwakkil mengatakan, tolong ini jual tanah ini seharga sekitar Rp. 100 juta hingga Rp. 150 juta. Maka pihak wakil tidak menjual di luar ketentuan harga di atas. Semisal dia ingin dapat untung dengan cara menjual Rp. 200 juta. Beda halnya, jika memang pihak mewakkil dari awal memberikan kebebasan agar wakil menjual tanah itu seharga minimal Rp. 100 juta dan boleh dijual berapa saja boleh sebagai keuntungan buat wakil, maka dalam kasus ini, wakil sah menjual barang tanah itu melebihi harga yang ditetapkan oleh muwakkil. ${ }^{19}$

\section{Akad Ijarah (Sewa)}

Akad ijarah dalam bahasa Indonesia disebut akad sewa menyewa. Ijarah adalah akad terhadap satu manfaat yang menjadi maksud dan diketahui waktu dan jaraknya serta bisa diserahterikan barangnya, selain itu barang yang disewakan itu juga harus barang-barang legal dan diperboleh untuk disewakan.

\footnotetext{
${ }^{18}$ Ibnu Qasim, A-Tarsyih, (Beirut: Dar Al-Kutub, t.t.), hal. 76.

${ }^{19}$ Ibid. Hal. 389.
} 
Dalam akad ijarah ini diharuskan adanya uang sewa yang diketahui atau disepakati bersama. ${ }^{20}$

Ulama fikih sepakat bahwa akad ijarah ini diperbolehkan dalam syariat Islam. Salah satu dasar hukum diperbolehkannya akad ijarah adalah firman Allah swt dalam al-Qur'an Surat Al-Talaq ayat (6);

$$
\text { فان أرضعن لكم فأتو هن أجور هن ...الاية }
$$

Jika mereka menyusui (anak-anak kalian) maka berikanlah upah atau imbalannya kepada mereka.....(QS. Al-Talaq: 6) ${ }^{21}$

Selain Al-Qur'an, dalam hadits Sahih Muslim juga disebutkan tentang kebolehan akad ijarah.

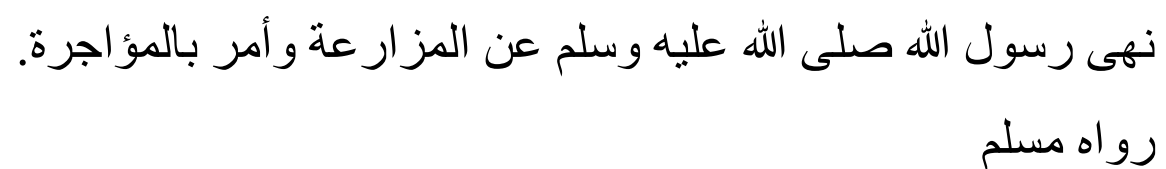

Rasulullah saw melarang akad muzara'ah (akad saling menanam di sawah dan tidak jelas kadar dan waktunya) dan Nabi saw memerintahkan (mebolehkan) akad sewa menyewa. (HR. Muslim) ${ }^{22}$

Adapun unsur-unsur akad ijarah ini sedikitnya ada tiga, yaitu:

a. 'Aqid atau orang yang akad. Yang dimaksud dengan orang yang akad ini adalah orang yang menyewa dan orang yang disewa atau orang punya barang yang disewakan dan orang yang menyewa barang tersebut.

b. Ma'qud 'alaih atau sesuatu yang diakad. Yang dimaksud dengan ma'qud 'alaih ini adalah manfaat atau barang yang disewa dan ongkos atau upah sewanya.

c. Kalimat Ijab dari orang yang mempunyai barang yang disewakan, dalam hal sewa barang. Namun jika akad sewa itu dalam praktik sewa jasa, maka ijab ini dari pihak pemilik jasa.

d. Kalimat Qabul dari orang yang menyewa barang, dalam hal sewa barang. Namun jika akad sewa itu dalam praktik sewa jasa, maka qabul ini dari pihak penyewa jasa. ${ }^{23}$

\section{Akad Ju'alah (Sayembara)}

\footnotetext{
${ }^{20}$ Muhammad Amin al-Kurdy, Tanwirul Qulub fi Mu'amalati 'Allam al-Ghuyub, Juz II, (Beirut: Darul Fikr, t.t.), hal. 263.

${ }^{21}$ Depag RI, Al-Qur'an dan Tafsirnya, Jilid I, Juz 1-2-3, (Yokyakarta: UII, 1991), hal. 280.

${ }^{22}$ Ibnu Hajjaj Muslim, Shohih Muslim, (Cairo: Dar Ihya’ Al-Kutub Al-'Arabiyah, t.t.), hal. 675.

${ }^{23}$ Muhammad Amin Al-Kurdi, Tanwir al-Qulub,. Hal. 264.
} 
Akad $J u$ 'alah ini hampir sama dengan akad sewa jasa, yaitu diberikannya satu imbalan atau upah kepada orang yang berjasa. Namun yang mebedakan. Perbedaan itu antara lain $;^{24}$ pertama, akad ju'alah terikat dengan dimulainya pekerjaan, sedangkan akad ijarah akan terikat sejak dimulainya akad, walaupun belum dimulai pekerjaanya. Kedua, imbalan atau upah dalam akad ju'alah diberikan saat menyelesaikan pekerjaannya, sedangkan upah dalam akad ijarah diberikan saat barang yang disewakan itu sudah dipakai. Ketiga, upah dalam akad ijarah diperbolehkan diberikan di awal transaksi, sedangkan upahnya akad ju'alah hanya diberikan setelah menyelesaikan pekerjaan. Keempat, dalam akad ijarah harus ada kejelasan tentang barang, manfaat, waktu yang disepakati, dan tujuannya harus jelas, sedangkan dalam akad ju'alah hanya disyaratkan adanya tugas dan manfaatnya, tidak menyebutkan waktu dan sejenisnya.

Adapun hukum akad ju'alah ini, ulama empat mazhab sudah banyak menguraikan dalam berbagai kitab fikih. Mazhab Syafii, Mazhab Maliki, dan Hanbali Hanbali menegaskan bahwa akad ju'alah ini diperbolehkan dalam syariat Islam. Hanya saja Imam Maliki menambahkan bahwa akad ju'alah ini diperbolehkan dengan jalan rukhsah (keringanan) untuk umat Islam. Berbeda dengan mazhab yang tiga tersebut, mazhab Hanafi hanya memperbolehkan ju'alah (sayembara) ini dalam urusan budah yang kabur, dengan adanya akad ju'alah ini diharapkan budaknya ada orang yang bisa mengembalikan dengan janji imbalan yang akan diberikan kepadanya.

Salah satu dasar paling kuat diperbolehkannya akad jualah adalah dalil hadits Al-Bukhari yang menceritakan seorang sahabat yang meruqyah atau mengobati orang terkena gigitan ular.

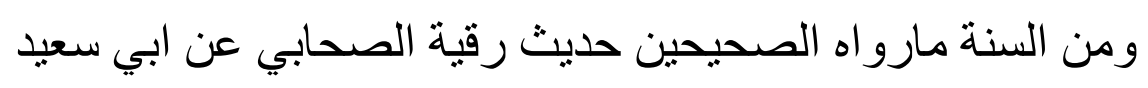

الخدري رضي الله عنه: أن أناسـا من أصحاب رسول الله صلى الله عليه
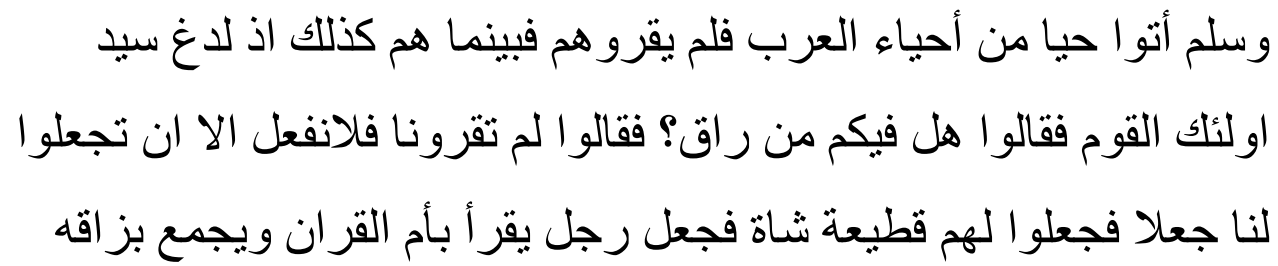
ويتفل فبرى الرجل فأتو ا بالثاة فقالو الانأخذها حتى نسال رسول الله صلى

\footnotetext{
${ }^{24}$ Ibrahim Al-Baijuri, Hasyiah Al-Baijuri, hal. 389.
} 


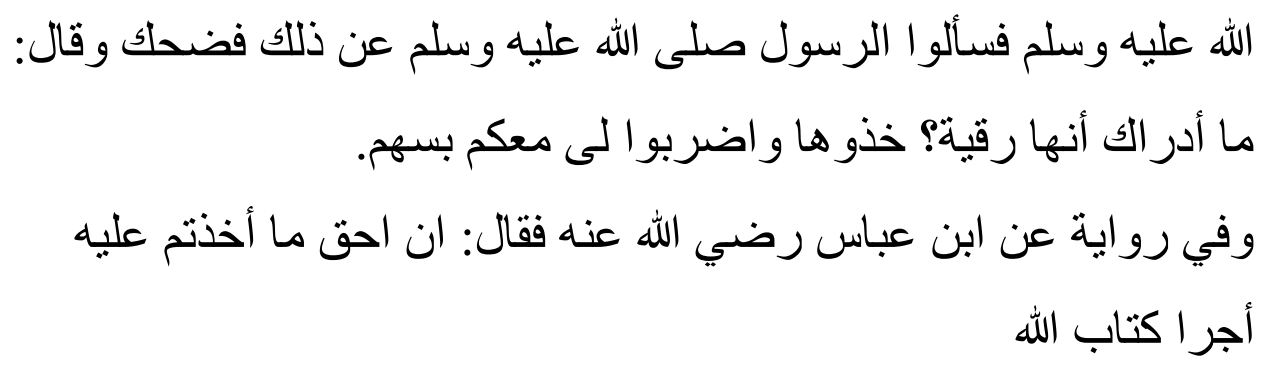

Di antara dalil kebolehan akad ju'alah adalah hadits dalam Sahih al-Bukhari dan Sahih Muslim, yaitu hadits tentang ruqyahnya seorang sahabat Nabi saw. Dari Abi Sa'id al-Khudri ra. Sesungguhnya sekelompok orang dari sahabat Nabi saw masuk ke kampung-kampung Arab namun mereka tidak dihormati oleh para penduduk setempat. Dalam keadaan seperti itu, ternyata ada seorang tokoh masyarakat di kampung itu yang digigit ular berbisa. Para penduduk bertanya: Adakah di antara kalian yang bisa mengobatinya? Para sahabat menjawab, kalian tidak menghormati kami. Kami tidak akan melakukannya (pengobatan) kecual jika kalian memberi kami upah. Maka mereka pun sepakat akan memberi seekor kambing. Maka salah seorang sahabat Nabi ada yang mulai membacakan surat alFatihah kemudian setelah mengumpulkan ludah dan disemburkan ke anggota tubuh orang yang digigit ular tadi, lalu yang sakit tersebut sembuh seketika. Para penduduk kampung itupun memenuhi janjinya dengan memberikan seekor kambing kepada sahabat Nabi yang mengobatinya. Singkat cerita, para sahabat pada Nabi terkait dengan upah seekor kambing tersebut, maka Nabi pun memperbolehkannya.

Selain itu, dalam akad ju'alah ini ada empat hal yang harus diperhatikan, yaitu: $:^{25}$

a. Adanya akad atau shighat yang diucapkan oleh masing-masing yang punya sayembara maupun peserta sayembara.

b. Adanya dua pihak yang saling akad. Satu pihak sebagai pemilik sayembara dan pihak yang satunya sebagai peserta yang ikut sayembara tersebut.

c. Adanya pekerjaan yang akan dilakukan oleh peserta sayembara

d. Adanya upah yang akan diberikan kepada peserta sayembara setelah selesai menjalankan tugasnya.

\section{E. Jual Beli Online dalam Perspektif Fikih Muamalah}

Bisnis online yang buming pada saat ini, khusus pada saat pandemi Covid-19, butuh dijelaskan statusnya secara syariat. Akad apa yang paling cocok disematkan pada praktik bisnis online ini? Namun yang jelas, bisnis online ini selain dikarenakan kebuthan mendasar bagi para pelaku bisnis, juga banyak manfaat yang dirasakan oleh semua pihak. Manfaat itu dirasakan oleh para pelaku usaha micro dan macro, juga dirasakan oleh para konsumen, sebab dengan adanya bisinis online ini, mereka tidak perlu keluar rumah, tidak perlu naik

\footnotetext{
${ }^{25}$ Muhammad Syaraf al-Nawawi, Al-Majmu', (Bairut: Dar Al-Kutub Al-Ilmiah, t.t.), hal. 367.
} 
kendaraan, tidak perlu jalan kaki, tidak perlu ini dan itu. Dalam bisnis online ini hanya dibutuh Hand Phone (HP) yang aktif tentunya yang ada kuota internetnya.

Dalam praktik bisnis atau jual beli online ini, sepintas mirip dengan jual beli bisa, namun barangnya hanya kelihatan dalam layar HP. Jika dilihat dari sisi pesan dan memesan, maka sepintas lalu bisnis ini mirip dengan akad salam dalam fikih Islam. Namun jika dilihat dari sisi iklan-iklan yang ada di medsos, maka bisnis online ini mirip dengan akad ju'alah (sayembara). Selain itu, jika dilihat dari sisi, seller dan reseller maka bisnis online ini juga mirip dengan akad wakalah. Ada satu lagi, yaitu jika dilihat dari bonus-bonus yang dijanjikan kepada para pelaku bisnis yang bisa mempromosikan dan menjualkan barang dengan jumlah tertentu, maka bisnis ini termasuk akad ijarah.

Maka dalam tulisan ini, bisnis online akan dicocokan dengan akad bai' (jual beli biasa), akad salam (pesanan), akad ju'alah (sayembara), akad wakalah (perwakilan), akad ijarah (sewa).

a. Bisnis online mirip dengan akad bay'i (jual beli)

Sebagaimana penjelasan sebelumnya, bahwa syarat jual beli yang sah diharuskan adanya mabi' (barang yang diperjualbelikan) ada dan terlihat. Dengan demikian, jika barang yang diperjualbelikan, belum ada atau tidak kelihatan maka akad jual belinya tidak sah dan tidak jadi, paling tidak dalam kitab fikih disebut dengan istilah bay' fasid (jual belik yang rusak). Dalam praktik bisnis online, yang dipromosikan atau yang akan diperjualkan belikan, terkadang memang barangnya belum dan terkadang barang sudah ada namun hanya diperlihat dalam bentuk gambar. Oleh karena itu, untuk menjawab status bisnis online dalam perspektif akad bay' maka pilah-pilah. Jika barang yang dipromosikan atau ditawarkan itu belum ada, maka jelas akadnya tidak sah. Namun jika barangnya sudah ada akan tetapi tidak kelihatan barang aslinya, melainkan hanya gambar yang dipajang di media sosial, maka ada perbedaan pendapat di antara ulama fikih. Ulama salaf mengatakan, barang yang ada di layar HP atau di laman medsos itu dianggap tidak ada, sehingga akad jual belinya tidak sah. Berbeda dengan ulama salaf, para ulama modern dan ulama kontemporer menegaskan bahwa saat ini kecanggihan teknologi itu dapat dijadikan sebagai alat bukti bahwa barang itu ada atau tidak. Artinya, foto barang yang terpapang di medsos itu sebagai representasinya adanya barang itu sebenarnya. Oleh karena itu, akad jual beli online ini, masuk jual beli biasa dan hukum sah.

b. Bisnis online mirip dengan akad salam (pesanan)

Dalam paparan penulis sebelumnya, khususnya pada sub bab akad salam, sudah dijelaskan bahwa dalam praktik akad salam, selain barang yang dipesan itu harus jelas, juga ra'sul mal (uang dari harga yang dipesan) harus diserahkan di 
awal, tidak boleh dihutang ataupun diberikan di belakang-dalam bahasa kekinian disebut dengan istilah COD. Dengan kata lain, penyerahan ra'sul mal di belakang atau dengan cara dihutang itu mempengaruhi keabsahan akad salam itu sendiri.

Dengan demikian, dalam bisnis online ini, memang sangat mirip dengan praktik akad salam. Barang belum. Pembeli memesan dengan kriteria yang jelas. Mulai dari warna, ukuran, hingga alamat penerima barang. Dalam hal pembayaran pun ada 3 macam. Ada yang harus bayar di awal, ada yang bayar separuh atau DP di awal, dan ada juga dibayar saat barang itu diterima oleh pihak pemesan atau biasa disebut dengan istilah COD.

Oleh karena itu, bisnis online ini jika dilihat dalam perspektif akad salam, maka status hukumnya diperinci. Jika jual beli online ini pembayaran secara lunas dari awal transaksi, maka bisnis online ini sah secara meyakinkan disebut dengan akad salam. Namun jika pembayaran dalam praktik bisnis atau jual beli online dibayar separuh di awal atau bahkan pembayaran secara COD, maka akad salam ini tidak sah dan tidak jadi transaksinya. Itupun jika praktik bisnis online ini dikembalikan ke dalam akad salam, sebab praktik akad salam, sepertinya penjelasan penulis di atas, pembayaran harus dilakukan di awal transaksi.

c. Bisnis online mirip dengan akad ju'alah (sayembara)

Akad ju'alah (sayembara) sebagaimana penjelasan pada sub bab akad sayembara sebelumnya, bahwa dalam praktik sayembara, selain harus ada kejelasan tugas yang harus dilakukan oleh para peserta sayembara, juga harus ada yang namanya upah dan upahnya diberikan setelah diselesaikannya pekerjaan itu.

Dalam praktik bisnis online, sering ditemukan, iklan dan promosi-promosi tertentu yang menjnjikan bonus bagi pelaku usaha bisnis online yang berhasil menjualkan barang dalam jumlah tertentu. Oleh karena itu, jika bisnis online ini dilihat dari perspektif akad ju'alah maka bisa juga dikatakan sebagai praktik ju'alah atau sayembara, sebab di dalamnya ditemukan ada upah atau bonus bagi yang berprestasi dalam menjualkan barang-barang yang dipromosikan tersebut.

d. Bisnis online mirip dengan akad wakalah (perwakilan)

Dalam praktik akad wakalah, diharuskan adanya dua pihak yang akad. Ada orang yang mewakilkan dan ada orang yang menerima perwakilan. Dalam kaitannya dengan bisnis online ini, ada dua pihak yang saling akad. Pemilik barang (seller) mewakilkan kepada reseller, kemudian reseller inilah yang menjualkan barang tersebut secara online maupun offline. 
Oleh karena itu, bisnis online ini jika dilihat dalam perspektif akad wakalah, maka memang ditemukan sisi-sisi wakalahnya itu. Yaitu penjual pertama mewakilkan pada penjual kedua untuk menjualkan barangnya. Dalam hal ini, akad wakalahnya sah. Dalam hal, konsumen membeli barang kepada reseller (wakil seller), tidak bisa disebut dengan akad wakalah.

e. Bisnis online mirip dengan akad ijarah (sewa)

Dalam praktik sewa menyewa, sebagaimana disebutkan di atas, bahwa sewa menyewa ini ada dua jenis. Sewa barang dan sewa jasa. Dalam praktik bisnis online ini, jelas pemilik barang biasanya meminta tolong reseller tingkat 1 dan seterusnya untuk mempromosikan barang jualannya dengan iming-iming bonus (upah) jika mereka berhasil menjualkan barang jualan tersebut. Dalam hal ini, seller meminta reseller untuk mempromosikan barang itu bisa dimasukkan dalam kategori akad sewa, khususnya sewa jasa. Namun dalam kaitannya para konsumen yang membeli barang dari reseller, tidak bisa disebut dengan akad sewa menyewa (ijarah).

F. Penutup

Sebagai penutup dalam kajian in, maka penulis simpulkan sebagai berikut:

Dalam praktik jual beli online, maka akad yang bisa disematkan kepada bisnis modern ini. Di dalamnya ada praktik wakalah, seller mewakilkan kepada reseller. Ada praktik ijarah, seller menyewa reseller untuk memasarkan barang dagangannya. Ada praktik ju'alah, seller mengumumkan (sayembara) kepada para reseller untuk berlomba-lomba memasarkan barangnya dengan bonus atau imbalan tertentu.

Dalam kajian ini yang menjadikan penekanannya adalah akad jual belinya kepada para konsumen, bukan seller ke reseller. Oleh karena itu, penulis menyimpulkan bahwa jual beli online dalam perspektif fikih mu'amalah dapat dikategorikan sebagai akad jual beli yang sah, jika barang yang ditawarkan itu memang sudah ada. Akan tetapi jika barang belum ada, melainkan hanya gambar dan barangnya belum berwujud (belum dibuat), maka hal itu dikategorikan sebagai akad salam yang sah apabilah ra'sul mal (uangnya) dibayar di awal, bukan sistem pembayaran di rumah (COD). 
Jurnal Keislaman, Vol. 4, No. 2, September

\section{DAFTAR PUSTAKA}

Asqalani, Ibnu Hajar. 2017. Bulugh Al-Maram. Cairo: Dar al-Syuruq.

Asqalani, Ibnu Hajar. 2000. Fath Al-Bari. Cairo: Dar Al-Ilm.

Baijuri, Ibrahim. t.t. Hasyiyah al-Baijuri 'ala Ibni Qasim al-Ghazi, Juz 1. Jeddah: Al-Haramain.

Depag RI, 1991. Al-Qur'an dan Tafsirnya, Jilid I, Juz 1-2-3. Yokyakarta: UII.

Hakim, Muhammad. t.t. Al-Mustadrak 'Ala Al-Sahihayn. Beirut: Dar Al-Kutub Al-Ilmiah

Jaziri, Abudrrahman . 2001. Al-Fiqh 'Ala Mazahib Al-Arba'ah. Beirut: Dar Al-Kutub Al-Ilmiah.

Kementerian Agama RI. 2010. Tafsir Kemenag RI. Jakarta: Kemenag.

Kurdi, Muhammad Amin. t.t. Tanwirul Qulub. Bairut: Darul Kutub al-Ilmiah.

Malibari, Zainuddin. 2018. Fathul Mu'in. Surabaya: Al-Hidayah.

Muslim, Ibnu Hajjaj. 2003. Shohih Muslim. Cairo: Dar Ihya’ Al-Kutub Al-‘Arabiyah.

Nawawi, Muhammad Syaraf. t.t. Al-Majmu’. Bairut: Dar Al-Kutub Al-Ilmiah.

Qardawi, Muhammad Yusuf. 2002. Al-Fiqh al-Mu'asir. Qatar: Al-Asyraq.

Qardawi, Muhammad Yusuf. 2007. Norma dan Etika Ekonommi Syari'ah, terj. Zainal Arifin. Jakarta: Gema Insani.

Qasim, Ibnu .t.t. A-Tarsyih. Beirut: Dar Al-Kutub.

Qasim, Ibnu. 1990. Fathul Qarib. Surabaya: Al-Hidayah.

Syarqawi, Muhammad. t.t. Hasyiyah Al-Syarqari. Libanon: Dar Al-Fikr.

Syata, Abu Bakar Muhammad. I'anat Al-Talibin, Juz III. Cairo: Dar al-Syuruq.

Zuhayli, Wahbah. 2004. Al-Fiqh al-Islami wa Adillatuh. Beirut: Dar Al-Kutuh Al-Ilmiah. 